\title{
An Overview of the Development of Groundwater Resources in India with special Reference to West Bengal and Kolkata
}

\author{
Bernadette John $^{\# 1}$, Rajib Das ${ }^{\# 2}$, Subhasish Das ${ }^{\# 3}$ \\ \#1 School of Water Resources Engineering, Jadavpur University, Kolkata 700032, West Bengal, \\ India, (Corresponding Author) \\ \#2 School of Water Resources Engineering, Jadavpur University, Kolkata 700032, West Bengal, \\ India
}

\#3 School of Water Resources Engineering, Jadavpur University, Kolkata 700032, West Bengal, India

\section{ABSTRACT}

Groundwater is the lifeline of any economy, the exhaustion of which can impair the normal livelihood of the society. It is of great importance especially in an agrarian economy like India, but it is found that the level of groundwater is falling in many parts especially in the states which are heavily dependent on agriculture. Even in the states of West Bengal the groundwater level shows a declining trend and many as such as six districts of it are arsenic affected. The same being with its capital, the city of Kolkata is also facing serious problem of water scarcity. Before it is too late, the measures should be urgently adopted to control the exploitation of groundwater - a renewable resource which when not judiciously used will become exhaustible. Mass awareness is the need of the hour and strict Governmental legislation can only control the problem. Community participants should be encouraged with rainwater harvesting and artificial recharge schemes. The study of groundwater being little difficult as it is not accessible freely but methods like drilling, vertical electrical sounding have helped in its studies even the use of remote sensing and geographical information system have open new avenues for groundwater research and laid the platform for further research.

Key words: groundwater depletion, artificial recharge, groundwater potential zone, agrarian economy, confined aquifer, legislative measures, land subsidence, soil water intrusion.

\section{INTRODUCTION:}

Groundwater is considered to be one of the most important resources of any Nation. It plays a vital role in ensuring livelihood security especially in the economies that depend heavily on agriculture. Groundwater being a renewable resource has become the "lender of last resort" [4]. In areas where surface water availability is less, people tap the groundwater. Thus, this resource is taken as the first indication of water scarcity. Never the less, the two systems - surface water and groundwater are considered to be a single resource ensuring their dependency. Over exploitation of groundwater results in reduced river flows, lower lake levels, and reduced recharges to wetlands and spring which affect the other areas of life like availability of drinking water, and water supplies to aquatic 
habitat. Since groundwater is freely available and less prone to pollution, this resource is tapped the most.

Groundwater is a free gift of nature, but this resource is not ubiquitous, the geological setting of a place plays an important role in the availability of ground water in the region. It is a rare resource in hand rocked area and is abundant in the flat deltaic region. Its availability also depends on the availability of the earth materials to transmit ground water which varies in terms of magnitude determined by this size, shape, interconnectedness and size of pores in different materials [4].

The over exploitation of groundwater for agriculture, industrial and domestic use has lead to the falling of groundwater level in many parts of the world especially India, due to which large awareness has been created and measures adopted for the development of this resource.

\section{INDIAN SCENARIO OF GROUNDWATER DEVELOPMENT}

India being an agrarian economy, the need for water resources development in the country is maximum.

India is the largest user of groundwater in the world. It is estimated that India uses around 230 cubic $\mathrm{km}$ of groundwater per year more than a quarter of the global total. More than $60 \%$ of the irrigated land under agriculture depends on groundwater as evident in Fig. 1. Apart from this $85 \%$ of the drinking water supply is drawn from here, thus it is the lifeline of the rural India. Over the years the number of tube wells is also on the rise thus, indicating a greater tapping of the resources. Even in urban areas with the increasing population and increasing industrial development the need for water supply is on the rise and more of groundwater is being tapped with the construction of millions of private wells, there has been a phenomenal growth in the exploitations of groundwater in the last few decades [15].

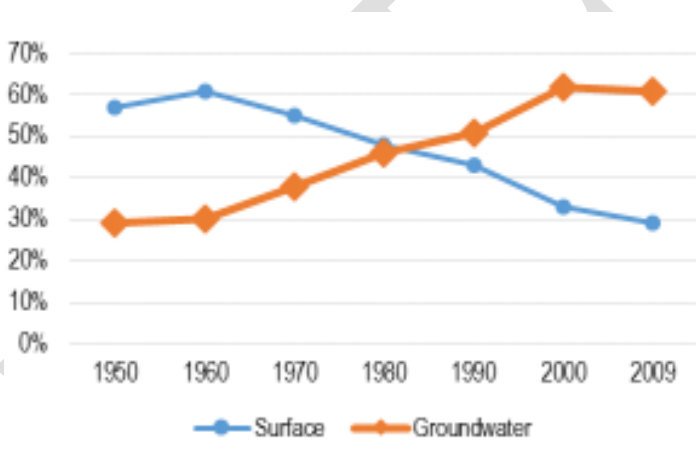

Fig 1: Increase in groundwater utilization for irrigation (PRS, 2014)

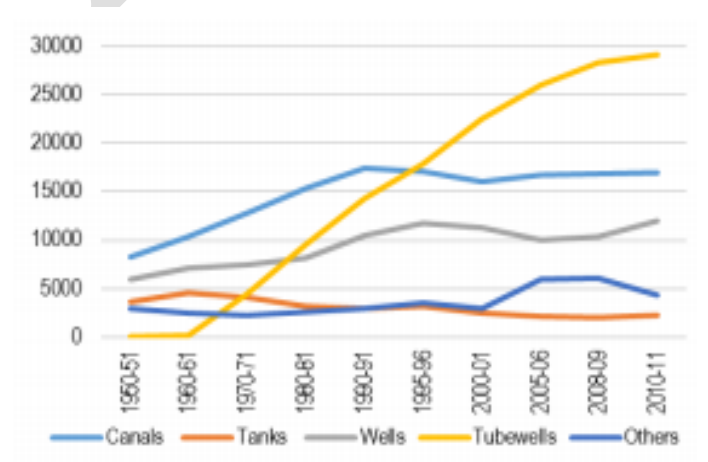

Fig 2 : Tube wells increasingly being the main source of irrigation (PRS, 2014)

As of April 2015, the annual water availability of the country as in natural flow of the river was about 1869 billion cubic meter (BCM/year) and the usable water resource of the country was estimated to be $1123 \mathrm{BCM} /$ year, due to the constraints of topography and uneven distribution of resources in different basins. The share of groundwater and surface water are being $433 \mathrm{BCM} / \mathrm{year}$ and $690 \mathrm{BCM} / \mathrm{year}$, respectively and the remaining for natural discharge. The increasing population has created pressure on the groundwater resource and the national per capital annual availability of water has been reduced from 1816 cubic meter in 2001 to 1544 cubic meter in 2011 leading to a $15 \%$ reduction. The Fig. 3 shows the depth to water level for the Indian states. 


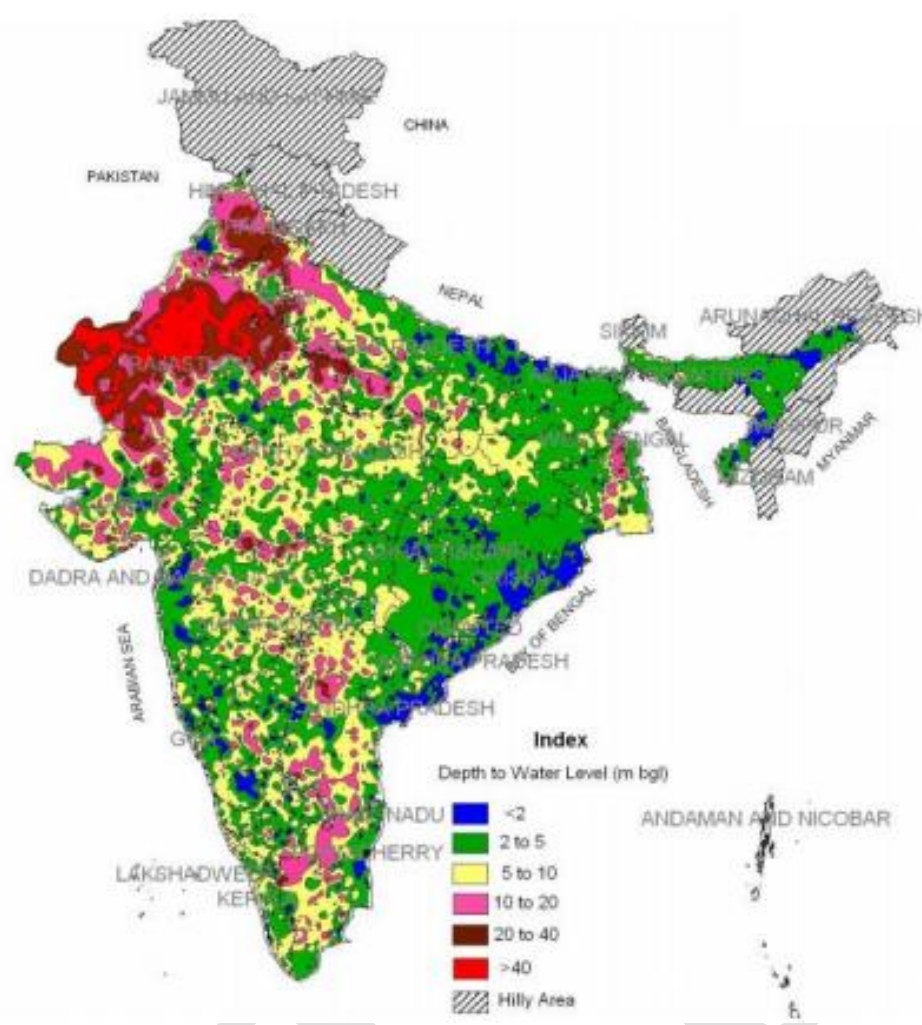

Fig 3: Depth to water level during pre monsoon in 2014 (Suhag, 2016)

The level of groundwater development is very high in Delhi, Haryana, Punjab and Rajasthan, where the values are $100 \%$ which implies that in these states the annual groundwater consumption is greater than annual recharge. In states like Himachal Pradesh, Tamil Nadu, Uttar Pradesh and Union Territory of Pondicherry, the level of groundwater development is $70 \%$ and above where as in other states of the country the water development being less than $70 \%$. The overall water development of the country has increased from $58 \%$ in 2004 to $62 \%$ in 2011 ; out of the total water extracted $89 \%$ of groundwater is used for irrigation.

Apart from reading the groundwater level, the quality of groundwater questionable in some parts of the country. Nearly $60 \%$ of all districts in the country are struggling with issue of availability or quality of groundwater.

According to the committee on Estimates 2014-15, 68 districts in 10 states of India are affected by high arsenic contamination. These states are Haryana, Punjab, Uttar Pradesh, Bihar, Jharkhand, Chhattisgarh, West Bengal, Assam, Manipur and Karnataka [27].

Awareness of water scarcity has been created amongst people and lot of work has been done in the field of groundwater. Ground water's importance is felt more in hard rock areas, where groundwater availability is meager. A study conducted to delineate the Groundwater Potential (GWP) zones and to analyze groundwater trend in Ranchi Urban Agglomeration, Jharkhand. The GWP zones were delineated using various terrain characteristics and modeled using analytical hierarchical process (AHP) in Geographical Information System (GIS) environment. The study reflected that the hard rock formations and increasing urbanization retarded groundwater recharge in the recharge and hence, artificial recharge is the next alternative [25]. These shallow ground water levels are directly related to geology and urbanization, climate change also affects the level of groundwater recharge. 
Study of groundwater, which is below the surface and which cannot be physically assessed except in dug wells and springs are a difficult research area. Study of groundwater remained limited due to the physical inaccessibility. The Central Ground Water Board (CGWB) has its monitoring stations, which monitor the water level all over the country, but it is difficult for an individual to research in this field due to physical inaccessibility. Remote sensing has played an important role in this regard and has helped in the study of groundwater. Remote sensing is based on assessing an object without actual contact. A groundwater interpretation is derived from the interpretation of lithology structure, relief, drainage density of any region. These multiple data sets can be used in the analysis of groundwater. Thus it is an indirect method of investigation of groundwater.

Remote sensing is a source of basic data, a science and a tool and GIS is a platform for the execution of the data collected through remote sensing. A Study conducted in west Godavari district of Andhra Pradesh successfully drew meaningful conclusions on the groundwater prospects of an area using GIS platform (ARC/INFO). The study reveals that GIS techniques are time and cost effective and can be employed successfully in the planning stages of a groundwater exploration program [3].

National Aeronautics and Space Administration (NASA) by the help of gravity recovery and climate experiments satellites showed that groundwater is being depleted at a mean rate of $4.0 \pm 1.0$ centimeter per year. Over the Indian states of Rajasthan, Punjab and Haryana (including Delhi) and with normal annual rainfall, using the terrestrial water storage - change observation and simulated the soil water variations from a data integrating hydrological modeling system to get the above result [8].

Even though remote sensing has set a bench mark in the study of groundwater still the result needs to be validated with ground truths.

\section{DEVELOPMENT OF GROUNDWATER IN WEST BENGAL}

The state of West Bengal is underlain by diverse rock types ranging from Archaean metamorphites to quaternary unconsolidated sediments. Approximately $75 \%$ of the state is covered by alluvial and deltaic deposits of sub recent to recent time and the remaining part - abounds in a wide variety of hard rocks. In West Bengal aquifer characteristics varies considerably from north to south and west to east. Out of 341 blocks most areas have aquifer under both water table as well as confined condition. The coastal districts are consist of 59 blocks, is under confined condition, Kolkata being one.

The surveys carried out by CGWB revealed that out of 462 analyzed wells 212 wells (36.21\%) have shown rise whereas 428 wells $(63.78 \%)$ have shown fall. The rise and fall of water level is mostly restricted within 0 to 2 meter of the remaining wells, $6.2 \%$ wells show $2 \sim 4$ meter rise and $1.5 \%$ wells show greater than 4 meter rise, 9\% wells show 2-4 meter fall and 3.9\% wells show greater than $4 \mathrm{~m}$ fall. Thus, indicating a gradual declining trend in water level in the state [26].

Apart from the falling trend in groundwater level, West Bengal faces the problem of water quality. In 1996, 37 administrative blocks were identified with arsenic. The areas affected with arsenic were all located in the upper delta plain, and are mostly in the abandoned meander belt. The source being geological this was proved with the Bore-hole sediment analysis. The high withdrawal of water may be the cause of arsenic leaching from the source [2]. 
The Sample analysis done in the district of Murshidabad revealed, that out of the total sample collected $26 \%$ of the tubewells were found to have arsenic about $50 \mathrm{micro} \mathrm{g} / \mathrm{L}$ while $53.8 \%$ had arsenic above 10 micro $\mathrm{g} / \mathrm{L}$. It was projected that 2.5 million and 1.2 million people were drinking arsenic contaminated water with concentrations above 10 and 50 micro g/L levels in the same affected districts of West Bengal [6].

Continuous exposure to Arsenic can cause cancer and other health ailments. Various techniques are employed to provide arsenic- free drinking water at an affordable cost. But a change in habit and mindset is required to bring a change. Harvesting rainwater and purification methods can be considered as an alternative [22].

The expansion of toxic arsenic has mainly taken place through the irrigated water, which has increased many folds with Green Revolution framework. Making the people scientifically aware and increasing community level participation is considered necessary for a long term sustainable development [30].

Dhar et al. [9-13] and Das et al. [21] worked on the effect on groundwater due to saline water intrusion phenomenon in coastal areas for South 24 Parganas district of West Bengal. Since long years ago the coastal zone of Purba Midnapur district of West Bengal was situated in Bay of Bengal at foothill of Rajmahal and Singbhum. Basically the coastal zone of Purba Midnapur district build by stratified layers which are formed through the deposition of silts [18,23] and boulders in years after years caring through Ganga, Bhagirathi and others. In some previous literatures it was discussed that groundwater recharging will be increased due to increase in rainfall [17,20,24].

\section{GROUNDWATER SCENARIO OF KOLKATA REGION}

Kolkata is located in the lower deltaic plain of the Ganga- Bhagirathi river basin, its geology consisting mainly of clay and clay loam. The upper clay layer extends to a depth of 10 to 25 meter below ground level ( $\mathrm{mbgl})$, below this is a sand layer extending up to a depth of 30 to $35 \mathrm{mbgl}$. Below this extends another clay layer up to a depth of 60 to $100 \mathrm{mbgl}$. Kolkata is mainly composed of confined aquifer, the upper aquifer being about 10 to 20 meter thick, the second occurring between the depth of 65 and 120 meter being about 30 to 50 meter thick, is the most potential and exploited aquifer of Kolkata [14].

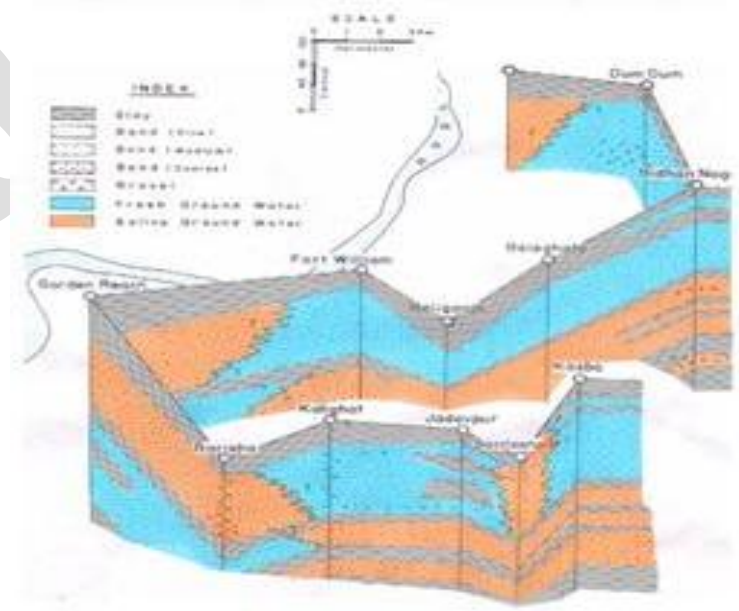

Fig 4: Sub-surface deposition of aquifers in Kolkata Municipal Corporation (KMC) area

(KMC, 2007) 
Kolkata is a highly populated city, whenever the water demand is not fulfilled; people tend to tap groundwater for their use. Heavy withdrawal of groundwater for domestic and industrial use has lead to a fall of 9.75 meter of piezometric level during a span of 25 years [1].

The city's groundwater is not same in all parts of the city, a number of saline or brackish water zones are present around the area, the mixing of this saline water with freshwater poses threat to the environment. Vertical Electrical Sounding (VES) was used for the identification of such zones [5].

Figure 4 shows the presence of the saline/brackish water over freshwater. In places like Garden Reach, Barisha, saline water overlies freshwater.

Due to the huge pumpage of groundwater a trough has been formed in the central Kolkata around Park Street, Camac Street, Fort William, Kalighat, Ballygunge, The long term trend of the monitoring stations located in Kolkata indicates a falling trend in both pre and post monsoon period for most of the wells. The rate of decline is estimated to be around 0.33 meter per year at the core of the trough and 0.11 meter per year at the periphery [7].

The piezometric level of Kolkata is very deep ranging between $10.68 \mathrm{mbgl}$ and $19 \mathrm{mbgl}$ during premonsoon period and between $8.25 \mathrm{mbgl}$ and $18.25 \mathrm{mbgl}$ during post monsoon. In larger part of the city, the piezometric level generally varies from $14.50 \mathrm{mbgl}-16.50 \mathrm{mbgl}$, due to huge withdrawal of groundwater for multiple uses [26].

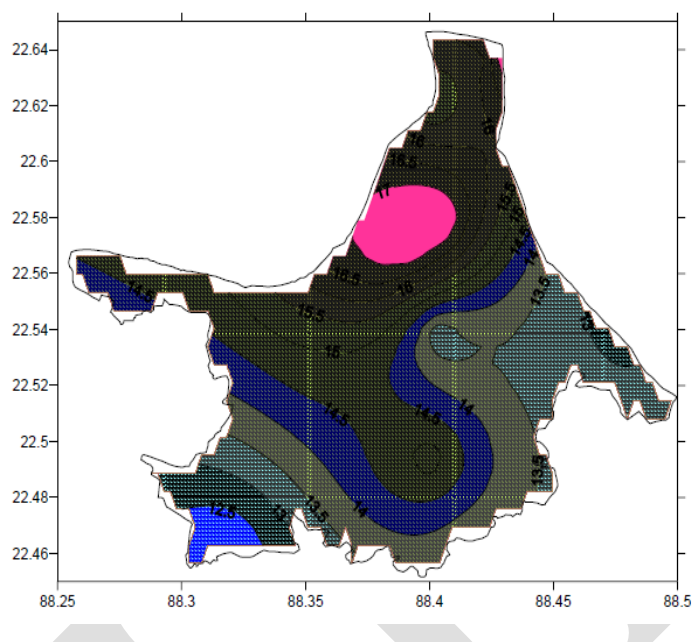

Fig 5: Pre- Monsoon Depth to Water Level $\operatorname{mbgl}(\mathrm{KMC}, 2007)$

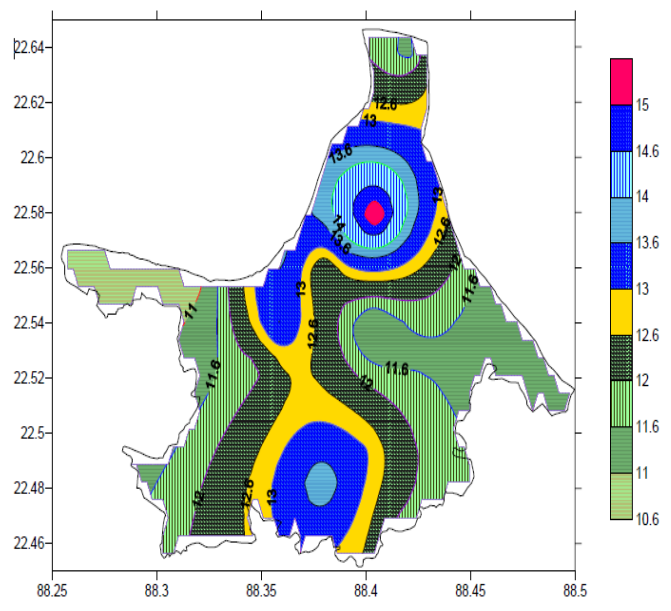

Fig 6: Post- Monsoon Depth to Water Level mbgl (KMC,2007)

Figures 5-6 show the pre monsoon and post monsoon water levels of the city. It is seen that the piezometric level varies between $12 \mathrm{mbgl}$ to $17 \mathrm{mbgl}$ during the pre monsoon period and between $10 \mathrm{mbgl}$ to $15 \mathrm{mbgl}$ during the post monsoon period for the year 2006.

In the recent sample testing it is found that arsenic content is more in south Kolkata than in other part of the city. The daily intake of arsenic in the contaminated water was estimated at 0.95 gram, thus, high risk of cancer. As for its toxicity ground water is not considered as a sustainable source of fresh water. Since, water tax is not imposed; it gives the owner the license to withdraw water, making its restoration difficult [28].

Water supply in the city is mainly from the river Hooghly through the Tala, Garden Reach, Jorabagan and Watganj pumping station. From 2005 KMC aimed to provide surface water to the 
entire Kolkata to reduce the pressure on ground water resources [27]. But it is witnessed that till date, especially in south Kolkata due to lack of surface water people are continuously tapping ground water for their day to day needs.

Groundwater of the confined aquifer in Kolkata is recharged from the adjoining areas of Nadia, Howrah, South 24 Parganas and also Hugli [26]. Some percentage of recharge also takes place from East Kolkata Wetlands, which can be detrimental to Kolkata's groundwater quality because of its polluted surface water.

There has been lot of research regarding the level and quality of groundwater resources, there is an urgent need to arrest the ground water problem in Kolkata before it becomes a societal hazard. Research needs to be carried out in the recharge zone even, to understand the problem in an integrated way.

\section{STEPS TAKEN BY THE GOVERNMENT}

Weak legislative policies are of the reason for the over exploitation of groundwater resources section 7(g) of the Easement Act, 1882 states that every owner of the land has right to collect and dispose within his own limits all water under land and on its surface which does not pass in a defined channel. The legal consequence of the above is that the owner of the land can dig wells in his lands and extract water. Since, there is lack of regulation for over extraction the depletion of groundwater continues CGWB identifies the over exploited and critical areas over the states, but the board does not have the right to stop groundwater extraction and can only make the owner aware [27].

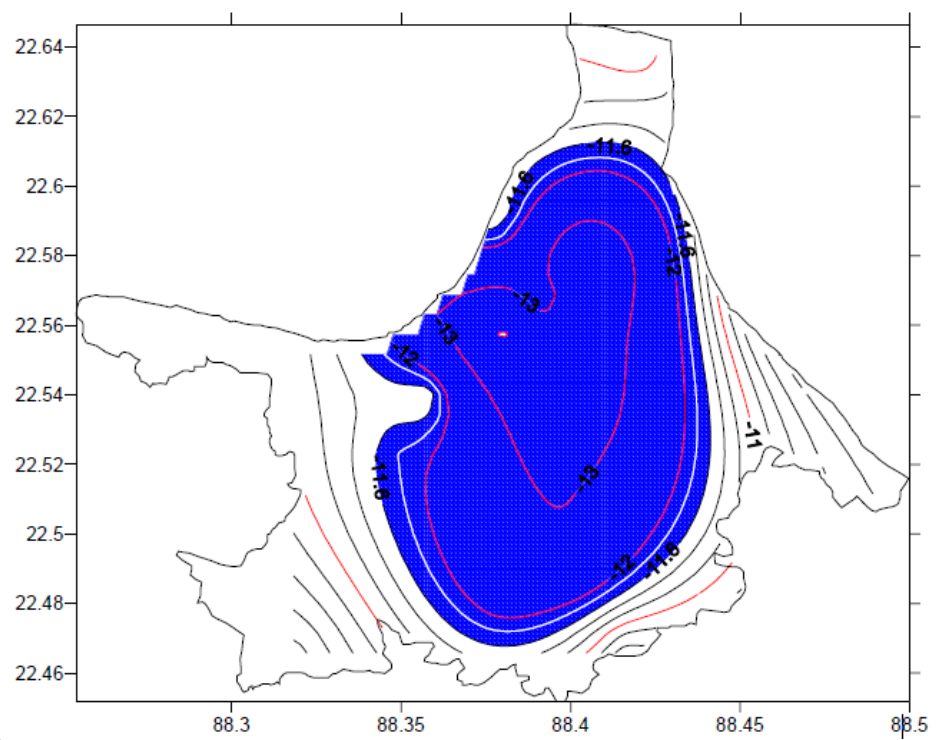

Fig. 7 Area of artificial recharge in KMC area (KMC, 2007)

Artificial recharge scheme has been taken under Central sector scheme at All India Soil and Land use Survey (AISLUS) building, Kolkata. The only way of artificial recharge in Kolkata being gravity hand recharge tube well using roof top rainwater because of the concrete surface direct recharge is not possible. A lot of awareness programme was undertaken to make the commoners aware of the problem. The area demarcated for artificial recharge in the city is shown in Fig. 7 [7]. 


\section{CONCLUSIONS}

Study of groundwater is attracting the attention of the researchers and the civic bodies due to its high importance. The exhaustion of groundwater can lead to hazardous situation - water crisis, loss of aquatic habitat, drying of surface water bodies even land subsidence. Thus immediate steps are needed to arrest the problem. Strict legislation should be involved and laws need to be properly executed and more community participation is required so that people understand the risk of groundwater depletion and work towards its development. Artificial Recharge and water harvesting techniques are the only next alternative. People should be encouraged to do so; every household should have water harvesting technique so that during the rainy season the dependency on the resource is reduced. Researches in the field should be encouraged; since groundwater is so much interconnected with other factors, all must be kept in mind when dealing with groundwater and not just over exploitation of resources. Thus the subject needs to be dealt in an integrated way.

\section{REFERENCES}

I.A.B. Biswas, and A.K. Saha, Environmental Hazards of the Recession of Piezometric Surface of Groundwater under Calcutta, Indian National Science Academy, Vol. 51(3), pp. 610-621, 1985.

II.D. Das, G. Samanta, B.K. Mandal, T.R. Chowdhury, C.R. Chanda, P.P. Chowdhury, G.K. Basu, and D. Chakraborti, Arsenic in ground water in six districts of West Bengal, India, Environmental Geochemistry and Health, Vol.18(1), pp.5-15, 1996.

III.M.V.V. Kamaraju, A. Bhattacharya, G.S. Reddy, G.C. Rao, G.S. Murthy, and T.C.M. Rao, Groundwater Potential Evaluation of West Godavari District, Andhra Pradesh State, India- A GIS Approach, The Groundwater Association , Vol. 34(2), 1996.

IV.W.M. Alley, T.E. Reilly, and O.L. Franke, Sustainability of Ground water Resources, U.S. Geological Circular 1186, 1999.

V.D.K. Saha, and K. Choudhury, Saline water Contamination of the Aquifer Zones of Eastern Kolkata, J. Ind. Geophys. Union, Vol. 9(4), pp. 241-247, 2005.

VI.M.M. Rahman, K.M. Sengupta, S. Ahamed, D. Lodh, B. Das, A.M. Hossain, B. Nayak, A. Mukherjee, D. Chakraborti, C.S. Mukherjee, S. Pati, C.K. Saha, K.S. PAlit, I. Kaies, K.A. Barua, and A.K. Asad, Murshidabad- one of the nine groundwater arsenic affected districts of West Bengal, India. Part I: magnitude of contamination and population at risk, Clin Toxicol(phila), Vol. 43(7), pp. 823-834, 2005.

VII.Groundwater Information Booklet, Kolkata Municipal Corporation, West Bengal, 2007.

VIII.M. Rodell, I. Velicogna, and J.S. Famiglietti, Satellite- based estimates of groundwater depletion in India, Nature, Vol. 460, pp. 999-1002, 2009.

IX.S. Dhar, S. Das, and A. Mazumdar, Salinity Intrusion Impact on the Piyali River of the Sundarbans, International Conference on Emerging Technologies in Environmental Science and Engineering, Aligarh, Uttar Pradesh, pp.383-39, 2009.

X.S. Dhar, S. Das, S.S. Ray, and A. Mazumdar, Environmental Monitoring of the Salt Water Intrusion Phenomenon of the Piyali River, Proceedings of National Conference on Advances in Environmental Engineering (AEE-09), Dept. of Civil Engg., NIT Rourkela, Orissa, pp. 377-382, 2009. 
XI.S. Dhar, S. Das, S.S. Ray, J. Debbarma, and A. Mazumdar, First Investigation of the Status of potable water availability of the Piyali River, National Seminar on Good Governance in Water Supply \& Sanitation Management in Context to Millennium Development Goal, pp. 121-126, 2009.

XII.S. Dhar, S. Das, S.S. Ray, J. Debbarma, and A. Mazumdar, Effects of Climate Change on the Crop Productivity in the Saline Soils of the Piyali River, 5th Asian Regional Conference of International Commission on Irrigation and Drainage (ICID), New Delhi, India, pp. 300, 2009.

XIII.S. Dhar, S. Das, S.S. Ray, J. Debbarma, and A. Mazumdar, First Investigation of the Climate Change Impact on the Crop Productivity of the Piyali River Region, 60th International Executive Council Meeting \& 5th Asian Regional Conference, New Delhi, India, 2009.

XIV.http://jcses.blogspot.in/2009/01/hydrogeology-of-kolkata.html

XV.Deep Wells and Prudence: Towards Pragmatic Action for Addressing Groundwater Overexploitation in India, World Bank, 2010.

XVI.S. Dhar, S. Das, S.S. Ray, and A. Mazumdar, Salt Water Intrusion into the Piyali River Aquifer of the Sundarbans, West Bengal, Proceedings of the National Conference on Groundwater Resource Development and Management in Hard Rocks- supported by DST, GoI, University of Pune, pp.35-36, 2010.

XVII.S. Das, D. Roy, A. Mazumdar, S. Chowdhury, and M. Majumder, Hydrological feasibility of a mini hydropower plant on Tiljuga River, Bihar, India, Water and Energy International, Vol. 69(12), pp. 30-37, 2012.

XVIII.B. Mukherjee, S. Das, and A. Mazumdar, Mathematical Analysis for the Loss of Future Storage Capacity at Maithon Reservoir, India, ARPN Journal of Engineering and Applied Sciences, Vol. 8(10), pp. 841-845, 2013.

XIX.PRS (2014), Agricultural Statistics at a Glance, Ministry of Agriculture.

XX.M. Chatterjee, R. De, D. Roy, S. Das, and A. Mazumdar, Hydrological Modeling Studies with HEC-HMS for Damodar Basin, India, World Applied Sciences Journal, Vol. 31(12) pp. 2148-2154, 2014.

XXI.S. Das, M. Nayek, S. Das, P. Dutta, and A. Mazumdar, Impact on Water Quality in Piyali River, Sundarbans, India due to Saline Water Intrusion, Indian Journal of Environmental Protection, Vol. 34(12), pp. 1010-1019, 2014.

XXII.T.K. Dey, P. Banerjee, M. Bakshi, A. Kar, and S. Ghosh, Groundwater Arsenic contamination in West Bengal: Current Scenario, Effects and Probable Ways of Mitigation, International Letters of Natural Sciences Online, Vol. 13, pp. 45-58, 2014.

XXIII.B. Mukherjee, S. Das, and A. Mazumdar, Environmental Study and Analysis of Silts Deposition at Maithon Reservoir, Indian Journal of Environmental Protection, Vol. 35(3), pp. 177 $187,2015$.

XXIV.S. Jana, M. Das, D. Roy, S. Das, and A. Mazumdar, Simulation of Hydrology climate change impact in a river basin in Eastern India, International Journal of Hydrology Science and Technology, Vol. 5(4), pp. 314-332, 2015.

XXV. A.Kumar, and A.C. Pandey, Geoinformatics based potential assessment in hard rock terrain of Ranchi urban environment, Jharkhand state (India) using MCDM- AHP techniques, Groundwater for Sustainable Development, Vol. 2, pp. 27-41,2016.

XXVI.CGWB, Central Ground Water Year Book of West Bengal \& Andaman \& Nicobar Islands (2014-2015), 2016. 
XXVII.R. Suhag, Overview of Groundwater in India (PRS), 2016.

XXVIII.D. Chakraborti, B. Das, M.M. Rahman, B. Nayak, A. Pal, M.K. Sengupta, S. Ahamed, M.A. Hossain, U.K. Chowdhury, B.K. Biswas, K.C. Saha, and R.N. Dutta, Arsenic in groundwater of the Kolkata Municipal Corporation (KMC), India: Critical review and modes of mitigation, Chemosphere, Vol. 180, pp. 437-447, 2017.

XXVIX.K.P. Maity, S. Das, and R. Das, Assessment of Groundwater Quality and Saline Water Intrusion in the Coastal Aquifers of Purba Midnapur District, West Bengal, India, Indian Journal of Environmental Protection, Vol. 379(1), pp. 31-40, 2017.

XXX.S. Bhowmick, S. Pramanik, P. Singh, P. Mondal, D. Chatterjee, and J. Nriagu, Arsenic in ground water of West Bengal, India: A review of human health risks and assessment of possible intervention options, Science of Total Environment, Vol. 612, pp. 148-169, 2018. 